\title{
ANALISIS FAKTOR-FAKTOR YANG MEMPENGARUHI INDEKS HARGA SAHAM GABUNGAN DENGAN METODE MODERATED REGRESSION ANALYSIS
}

\author{
Umamah
}

\section{INTISARI}

\begin{abstract}
Analisis regresi adalah suatu teknik yang digunakan untuk membangun suatu persamaan yang menghubungkan antara variabel independen dan variabel dependen. Dalam analisis regresi linier tidak hanya menghubungkan variabel independen dan dependen saja. Biasanya terdapat variabel yang dapat memperkuat bahkan memperlemah hubungan variabel independen dan variabel dependen atau biasa disebut juga dengan variabel moderasi. Penelitian ini mengambil data dari Bursa Efek Indonesia (BEI) yaitu Indeks Harga Saham Gabungan (IHSG) yang dipengaruhi oleh harga minyak mentah, harga emas dan jumlah uang beredar. Tujuan penelitian ini adalah mengestimasi parameter pada Indeks Harga Saham Gabungan yang dipengaruhi oleh harga minyak mentah, harga emas dan jumlah uang beredar di BEI dan menganalisis pengaruh variabel moderasi (kurs) terhadap IHSG. Metode yang digunakan adalah Moderated Regression Analysis dan analisis ini lebih umum digunakan dalam penelitian. Model yang diperoleh dari hasil penelitian analisis regresi variabel moderasi, diperoleh sebagai berikut: $Y=1,334457 e 223+X_{1}^{40,019}-X_{2}^{3,098}$ $\left(X_{1} Z\right)^{0,021}+\left(X_{2} Z\right)^{0,002}$. Berdasarkan penelitian, didapat faktor yang berpengaruh terhadap IHSG adalah harga minyak mentah, harga emas dan kurs. Setelah ditambah variabel moderasi faktor yang mempengaruhi IHSG bertambah dua variabel yaitu interaksi antara variabel harga emas dan kurs serta variabel harga minyak mentah dan kurs. Tetapi kursnya menjadi tidak berpengaruh terhadap IHSG. Pada kasus ini disebut dengan Pure Moderasi yaitu variabel moderasi yang memoderasi hubungan antara variabel independen dan variabel dependen dimana variabel $Z$ berinteraksi dengan variabel independen tanpa menjadi variabel independen.
\end{abstract}

Kata Kunci : Pure moderasi, Moderated Regression Analysis

\section{PENDAHULUAN}

Analisis regresi merupakan analisis yang paling populer di kalangan peneliti. Analisis itu mencerminkan bahwa selama ini setiap kejadian adalah saling terkait dan saling mempengaruhi. Analisis regresi merupakan analisis yang mempelajari bagaimana membangun sebuah model fungsional dari data untuk dapat menjelaskan atau meramalkan suatu fenomena alami atas dasar fenomena yang lain. Ada juga yang menyatakan bahwa analisis regresi merupakan suatu analisis mengenai hubungan antara dua variabel atau lebih yang umumnya dinyatakan dalam persamaan matematik [1].

Analisis regresi dengan variabel moderasi merupakan perkembangan dari regresi linier berganda dimana dalam regresinya terdapat variabel moderasi. Terdapat tiga macam metode dalam menganalisis regresi dengan variabel moderasi yaitu metode Moderated Regression Analysis (metode interaksi), metode selisih mutlak, dan metode residual. Pada penelitian ini menggunakan metode Moderated Regression Analysis, karena analisis ini lebih umum digunakan dalam penelitian manajemen strategi [2]. Metode Moderated Regression Analysis dilakukan dengan mengalikan dua variabel yaitu variabel moderasi dan variabel independen [3].

Ada beberapa faktor yang mempengaruhi naik turunnya IHSG di Bursa Efek Indonesia, yaitu harga minyak mentah, harga emas dan jumlah uang beredar serta kurs sebagai variabel moderasi. Setiap kenaikan atau penurunan harga minyak dapat berdampak pada perekonomian negara penghasil minyak. Bagaimanapun, negara yang mengimpor minyak lebih rentan terhadap perubahan harga minyak karena minyak dihargai dan dijual dalam dollar. Emas banyak digunakan untuk 
mengendalikan defisit ekonomi suatu negara. Selain itu emas merupakan salah satu komoditi yang mempengaruhi bursa saham. Naik turunnya harga emas akan berpengaruh terhadap IHSG di BEI. Jumlah uang beredar adalah total persediaan uang dalam perekonomian pada periode tertentu yang biasanya dalam kurun waktu satu tahun anggaran. Jika jumlah uang beredar meningkat maka IHSG akan naik. Begitu pula sebaliknya, jika jumlah uang beredar menurun, maka IHSG juga akan menurun. Kurs (exchange rate) atau nilai tukar mata uang adalah pertukaran antara dua mata uang yang berbeda, yaitu merupakan perbandingan nilai atau harga antara kedua mata uang [3]. Kurs dapat direpresentasikan sebagai sejumlah mata uang lokal yang dibutuhkan untuk membeli satu unit mata uang asing.

Tujuan dari penelitian ini adalah melakukan estimasi parameter pada IHSG yang dipengaruhi oleh harga minyak mentah, harga emas dan jumlah uang beredar di BEI periode 2010 - 2017 dan menganalisis pengaruh variabel moderasi terhadap IHSG di Bursa Efek Indonesia periode 2010 2017.

\section{Analisis Regresi Linear Berganda}

Analisis regresi berganda merupakan analisis yang digunakan untuk menganalisis pengaruh dari satu atau lebih variabel independen terhadap variabel dependen, dengan tujuan untuk mendapatkan nilai prediksi yang baik. Model analisis regresi linear berganda dapat ditulis sebagai berikut [5]:

$$
\begin{array}{cl}
\text { Dimana: } Y & : \text { variabel dependen } \\
\beta_{0} & : \text { konstanta } \\
\beta_{1}, \beta_{2}, \ldots, \beta_{k} & : \text { koefisien variabel independen } \\
X & : \text { variabel independen } \\
\varepsilon & : \text { error } \\
\mathrm{k} & : \text { banyaknya variabel independen }
\end{array}
$$

\section{Metode Kuadrat Terkecil}

Persamaan regresi yang paling baik adalah regresi yang mempunyai total kuadrat residual yang paling minimum. Untuk memperoleh total kuadrat residual yang paling minimum digunakan metode kuadrat terkecil atau Ordinary Least Square (OLS). Tujuan dari OLS adalah meminimumkan jumlah residual [4].

$$
\begin{array}{cl}
\text { Dimana: } Y & : \text { variabel dependen } \\
\beta_{0} & : \text { konstanta } \\
\beta_{1}, \beta_{2}, \ldots, \beta_{k} & : \text { koefisien variabel independen } \\
X_{i k} & : \text { data ke- } i \text { variabel independen ke- } k \\
\varepsilon_{i} & : \text { error } \\
\mathrm{k} & : \text { banyaknya variabel independen }
\end{array}
$$

Dalam metode kuadrat terkecil terdapat asumsi-asumsi yang harus terpenuhi yaitu residual berdistribusi normal, non heterokedastisitas, non multikolinearitas dan non autokorelasi.

\section{Pengujian Parameter}

Pengujian parameter dilakukan untuk mengetahui pengaruh variabel independen terhadap variabel dependen. Pengujian parameter meliputi pengujian secara serentak (Uji-F) dan pengujian secara parsial (Uji-T) [5].

Uji-F digunakan untuk melakukan uji hipotesis koefisien (slope) regresi secara bersamaan, dengan kata lain digunakan untuk memastikan bahwa model yang dipilih layak atau tidak 
untukmenginterpretasikan pengaruh variabel independen terhadap variabel dependen. Rumus statistik uji-F yaitu :

$$
F=\frac{\frac{J K R}{k-1}}{\frac{J K S}{n-k}}
$$

Dengan hipotesis :

$H_{0}: \beta_{1}=\beta_{2}=\cdots=\beta_{k}=0$ (secara serentak variabel independen tidak berpengaruh terhadap variabel dependen)

$H_{1}$ : Paling sedikit terdapat satu $\beta_{i} \neq 0, i=1,2,3, \ldots, k$ (secara serentak variabel independen berpengaruh terhadap variabel dependen)

$H_{0}$ ditolak jika $F_{\text {statistik }}>F_{(a, k-1, n-k)}$ atau tolak $H_{0}$ jika p-value $<\alpha$, dengan $\alpha=0,05$

Uji-T digunakan untuk menguji koefisien regresi secara parsial. Pengujian dilakukan terhadap koefisien regresi populasi, apabila sama dengan nol yang berarti variabel independen tidak mempunyai pengaruh signifikan terhadap variabel dependen, atau tidak sama dengan nol yang berarti variabel independen mempunyai pengaruh signifikan terhadap variabel dependen [6].

Dengan hipotesis :

$$
t=\frac{b_{i}}{S E_{b_{i}}}
$$

$H_{0}: \beta_{i}=0, i=1,2, \ldots, k$ (tidak ada pengaruh variabel independen ke-i terhadap variabel dependen)

$H_{1}: \beta_{1} \neq 0, i=1,2, \ldots, k$ (ada pengaruh variabel independen ke-i terhadap variabel dependen)

$H_{0}$ di tolak jika $t_{\text {hit }}>t_{\left(\frac{\alpha}{2} n-k-1\right)}$ atau p-value $<\alpha$, dengan $\alpha=0,05$

\section{Koefisien Determinasi}

Koefisien determinasi menjelaskan variasi pengaruh variabel independen terhadap variabel dependen atau dapat pula dikatakan sebagai proporsi pengaruh seluruh variabel independen terhadap variabel dependen. Nilai koefisien determinasi dapat diukur oleh nilai $R$-Square $\left(R^{2}\right)$ atau Adjusted $R$ Square $\left(R^{2} A d j\right)$. Nilai $R^{2}$ dapat dihitung dengan rumus sebagai berikut [6].

$$
R^{2}=1-\frac{\sum\left(Y_{i}-\hat{Y}\right)^{2}}{\sum\left(Y_{i}-\bar{Y}_{i}\right)^{2}}
$$

Dengan $Y_{i}$ adalah observasi ke i, $\hat{Y}$ adalah ramalan ke-i, dan $\bar{Y}$ adalah rata-rata. Untuk nilai $R^{2} A d j$ dihitung dengan rumus sebagai berikut.

$$
\text { Adjusted } R \text {-Square }\left(R^{2} A d j\right)=1-\left(1-R^{2}\right) \frac{N-1}{N-k-1}
$$

Dengan $\mathrm{N}$ adalah banyaknya individu dan $\mathrm{k}$ adalah banyaknya variabel independen.

\section{ANALISIS REGRESI VARIABEL MODERASI}

Variabel moderasi adalah variabel yang dapatmemperkuat atau memperlemah hubungan antara variabel independen dan dependen. Variabel moderasi bisa berbentuk kualitatif (kode, kategori) atau kuantitatif (skor) yang mempengaruhi hubungan antar variabel dependen (Y) dan independen (X) [7]. Dalam konsep hubungan sebab-akibat, jika $\mathrm{X}$ adalah variabel independen dan $\mathrm{Y}$ adalah variabel dependen, maka $\mathrm{Z}$ adalah variabel moderasi yang mempengaruhi hubungan dari $\mathrm{X}$ dan $\mathrm{Y}$. Untuk menggambarkan model hubungan moderasi dapat dilihat pada Gambar 1. 


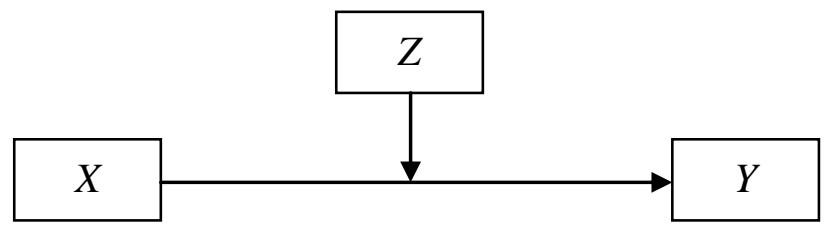

\section{Gambar 1. Model Regresi Variabel Moderasi Dengan Satu Varaiabel Independen}

Interpretasi dari Gambar 1 adalah variabel independen $(\mathrm{X})$ yang dimoderasi oleh variabel moderating (Z) terhadap variabel dependen $(\mathrm{Y})$. Variabel yang dimoderasi hanya merupakan variabel tunggal, yaitu $X$. Pada kenyataannya seringkali variabel yang dimoderasi oleh variabel moderasi tidak hanya satu variabel saja, tetapi dapat terdiri dari dua variabel atau lebih. Untuk menggambarkan model hubungan moderasi yang lebih dari satu variabel independen dapat dilihat pada Gambar 2.Variabel independen yang dihubungkan dengan variabel moderasi.

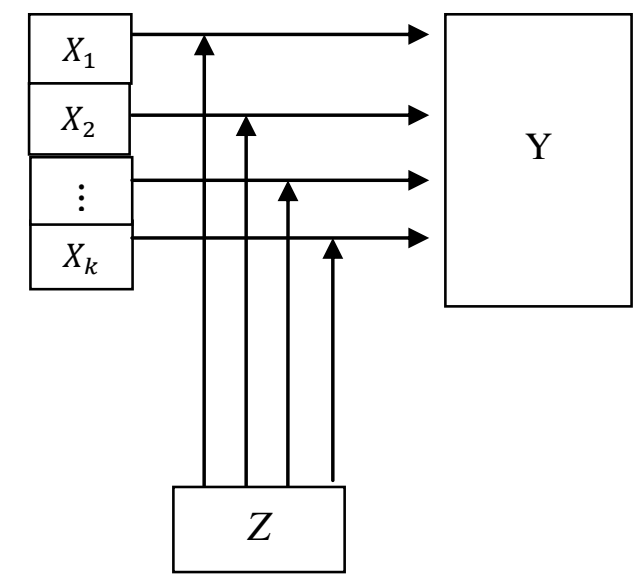

\section{Gambar 2 Model Regresi Variabel Moderasi Lebih Dari Satu Variabel Independen}

Berdasarkan Gambar 2 dapat dijelaskan bahwa :

$\begin{array}{ll}X_{1}, X_{2}, \ldots, X_{k} & =\text { Variabel Independen } \\ Z & =\text { Variabel Moderasi antara variabel } X \text { dengan } Y \\ Y & =\text { Variabel Dependen }\end{array}$

Interpretasi pada Gambar 2 adalah sebagai berikut.

- Variabel Independen $X_{1}$ dimoderasi oleh variabel moderating $(\mathrm{Z})$ terhadap variabel dependen $\mathrm{Y}$

- Variabel Independen $X_{2}$ dimoderasi oleh variabel moderating $(Z)$ terhadap variabel dependen $Y$

- Variabel Independen $X_{k}$ dimoderasi oleh variabel moderating (Z) terhadap variabel dependen $Y$

Klasifikasi moderasi dapat diidentifikasikan sebagaimana contoh berikut, jika $X$ adalah variabel independen, $Y$ adalah variabel dependen dan $Z$ adalah variabel moderasi maka persamaan regresi yang dapat dibentuk adalah sebagai berikut [7]:

- $\hat{Y}_{i}=b_{0}+b_{1} X_{i}$, tanpa melibatkan variabel moderasi

- $\hat{Y}_{i}=b_{0}+b_{1} X_{i}+b_{2} Z$, melibatkan variabel moderasi, yaitu $Z$

- $\hat{Y}_{i}=b_{0}+b_{1} X_{i}+b_{2} Z+b_{3} X_{i} Z$, melibatkan variabel independen dan variabel moderasi

a. Variabel Moderasi Murni (Pure Moderasi)

Pure moderasi adalah jenis variabel moderasi yang dapat diidentifikasikan melalui koefisien $b_{2}$ dan $b_{3}$ pada Persamaan 5 yaitu jika koefisien $b_{2}$ dinyatakan tidak signifikansi tetapi koefisien $b_{3}$ signifikansi secara statistika. Pure moderasi merupakan variabel moderasi yang memoderasi hubungan antara variabel independen dan variabel dependen dimana variabel moderasi murni berinteraksi dengan variabel independen tanpa menjadi variabel independen.

b. Variabel Moderasi Semu (Quasi Moderasi) 
Quasi moderasi adalah jenis variabel moderasi yang dapat diidentifikasi melalui koefisien $b_{2}$ dan $b_{3}$ dalam Persamaan 5 yaitu jika koefisien $b_{2}$ dinyatakan signifikan dan koefisien $b_{3}$ signifikan secara statistika. Quasi moderasi merupakan variabel yang memoderasi hubungan antara variabel independen dan variabel dependen dimana variabel moderasi semu berinteraksi dengan variabel independen sekaligus menjadi variabel independen.

c. Variabel Moderasi Potensial (Homologiser Moderasi)

Homologiser moderasi adalah jenis variabel moderasi yang dapat diidentifikasikan melalui koefisien $b_{2}$ dan $b_{3}$ dalam Persamaan 5 yaitu jika koefisien $b_{2}$ dinyatakan tidak signifikan dan koefisien $b_{3}$ tidak signifikan secara statistika. Homologiser moderasi merupakan variabel yang potensial menjadi variabel moderasi mempengaruhi kekuatan hubungan antara variabel independen dan variabel dependen. Variabel ini tidak berinteraksi dengan variabel independen dan tidak mempunyai hubungan yang signifikan dengan variabel dependen.

d. Variabel Prediktor Moderasi (Prediktor Moderasi Variabel)

Prediktor moderasi adalah jenis variabel moderasi yang dapat diidentifikasikan melalui koefisien $b_{2}$ dan $b_{3}$ dalam Persamaan 5 yaitu jika koefisien $b_{2}$ dinyatakan signifikan dan koefisien $b_{3}$ tidak signifikan secara statistika. Artinya variabel moderasi ini hanya berperan sebagai variabel independen dalam model hubungan yang dibentuk.

\section{ANALISIS REGRESI DENGAN METODE MODERATED REGRESSION ANALYSIS}

Analisis regresi dengan metode Moderated Regression Analysis merupakan aplikasi khusus regresi linier berganda dimana dalam persamaan regresinya mengandung unsur interaksi (perkalian dua atau lebih variabel independen) dengan rumus Persamaan 6 [7].

$$
Y=\beta_{0}+\beta_{1} X_{i}+\beta_{2} Z+\beta_{2} X_{i} Z+\varepsilon_{i}
$$

Variabel perkalian antara $X$ dan $Z$ disebut juga perkalian interaksi karena menggambarkan pengaruh moderasi variabel $Z$ terhadap hubungan $X$ dan $Y$.

Analisis regresi moderasi dengan metode Moderated Regression Analisis dilakukan dengan langkah-langkah sebagai berikut [7]:

1. Meregresikan $X$ dan $Z$ terhadap $Y$, diperleh persamaan sebagai berikut ini :

$$
Y=\beta_{0}+\beta_{1} X_{i}+\beta_{2} Z
$$

2. Mengalikan $X$ dengan $Z$ yang menjadi variabel moderasi

3. Meregresikan $X, Z$ dan variabel interaksi $(X Z)$ terhadap $Y$, diperoleh persamaan sebagai berikut :

$$
Y=\beta_{0}+\beta_{1} X_{i}+\beta_{2} Z+\beta_{3} X_{i} Z
$$

4. Menarik kesimpulan dengan kriteria klasifikasi variabel moderasi.

\section{HASIL DAN PEMBAHASAN}

\section{Data Sekunder}

Data dalam penelitian ini berupa data harga saham di Bursa Efek Indonesia sebagai variabel dependen yaitu data Indeks Harga Saham Gabungan (IHSG) (Y) yang dipengaruhi oleh beberapa faktor sebagai variabel independen yaitu harga minyak mentah dunia $\left(X_{1}\right)$, harga emas $\left(X_{2}\right)$, dan jumlah uang beredar $\left(X_{3}\right)$ serta sebagai variabel moderasinya kurs $(Z)$. Data diperoleh dari www.yahoofinance.com. Data dalam penelitian ini merupakan data bulanan dari bulan Januari 2010 sampai dengan bulan Desember 2017.

Hasil analisis deskriptif yang menggabungkan keadaan data disajikan pada Tabel 1 
Tabel 1 Hasil Perhitungan Statistika Deskriptif

\begin{tabular}{cccccc|}
\hline Variabel & $\mathrm{N}$ & Minimum & Maximum & Mean & Std. Deviasi \\
\hline $\mathrm{Y}$ & 96 & $2.549,03$ & $6.355,65$ & $4.527,99$ & 846,11 \\
$x_{1}$ & 96 & $2.066 .480,99$ & $5.419 .165,05$ & 75,69 & 23,30 \\
$x_{2}$ & 96 & $1.060,30$ & $1.828,50$ & $1.350,20$ & 194,65 \\
$x_{3}$ & 96 & $2.066 .480,99$ & $5.419 .165,05$ & 3.681 .487 .94 & $976.325,45$ \\
$\mathrm{Z}$ & 96 & $8.532,00$ & $14.396,10$ & $1.942,78$ & $11.206,66$ \\
\hline
\end{tabular}

Sumber : Data Olahan

Dari Tabel 1 dapat di interpretasikan bahwa jumlah variabel adalah sebanyak 96 sampel. Nilai maksimum dari IHSG sebesar 6.355,65 nilai minimum sebesar 2.549,03 dengan rataan sebesar $4.527,99$ dan standar deviasi sebesar 846,11 . Nilai maksimum dari variabel harga minyak mentah adalah 5.419.165,05 nilai minimum 2.066.480,99 dengan rataan sebesar 75,69 dan standar deviasi sebesar 23,30. Nilai maksimum dari variabel harga emas adalah 1.828,50 nilai minimum 1.060,30 dengan rataan sebesar 1.350,20 dan standar deviasi sebesar 194,65. Nilai maksimum dari variabel jumlah uang beredar adalah 5.419.165,05 nilai minimum 2.066.480,99 dengan rataan sebesar 3.681.487,94 dan standar deviasi sebesar 976.325,45. Nilai maksimum dari variabel moderasi (kurs) adalah 14.396,10 nilai minimum 8.532,00 dengan rataan sebesar 1.942,78 dan standar deviasi sebesar $11.206,66$.

\section{Estimasi Dan Pengujian Parameter Regresi}

Estimasi parameter model ini dilakukan dengan metode $O L S$ untuk memperoleh faktor-faktor yang signifikan terhadap variabel dependen. Hasil estimasi parameter yang diperoleh disajikan pada Tabel 2 yaitu sebagai berikut.

Tabel 2 Hasil Estimasi Parameter

\begin{tabular}{|c|c|c|c|c|c|}
\hline \multirow{2}{*}{ Model } & \multicolumn{2}{|c|}{ Untandardized Coefficients } & \multirow{2}{*}{$\begin{array}{c}\text { Standardized Coefficients } \\
\text { Beta }\end{array}$} & \multirow{2}{*}{$\mathrm{T}$} & \multirow{2}{*}{ Sig } \\
\hline & B & Std. Error & & & \\
\hline Constant & $-4253,73$ & 869,63 & & $-4,891$ & 0,000 \\
\hline$x_{1}$ & 8,258 & 3,104 & 0,227 & 2,661 & 0,009 \\
\hline$x_{2}$ & 1,774 & 0,317 & 0,408 & 5,599 & 0,000 \\
\hline$x_{3}$ & 1,386Е006 & 0,000 & 0,168 & 1,718 & 0,089 \\
\hline $\mathrm{Z}$ & 0,469 & 0,057 & 1,078 & 8,250 & 0,000 \\
\hline
\end{tabular}

Sumber : Data Olahan

Dari Tabel 2 terlihat bahwa variabel $x_{3}$ tidak signifikan karena nilai signifikansi $>\alpha$ sehingga dilakukan estimasi parameter dan pengujian parameter yang signifikan dengan tingkat kepercayaan 5\%. Hasil estimasi parameter dapat disajikan pada Tabel 3.

Tabel 3 Hasil Estimasi Parameter

\begin{tabular}{|c|c|c|c|c|c|}
\hline \multirow{2}{*}{ Model } & \multicolumn{2}{|c|}{ Untandardized Coefficients } & \multirow{2}{*}{$\begin{array}{c}\text { Standardized Coefficients } \\
\text { Beta }\end{array}$} & \multirow[b]{2}{*}{$\mathrm{T}$} & \multirow{2}{*}{ Sig } \\
\hline & B & Std. Error & & & \\
\hline Constan & $-4737,59$ & 831,47 & & $-5,698$ & 0,000 \\
\hline$x_{1}$ & 8,060 & 3,134 & 0,222 & 2,572 & 0,012 \\
\hline$x_{2}$ & 1,938 & 0,305 & 0,446 & 6,346 & 0,000 \\
\hline $\mathrm{Z}$ & 0,539 & 0,040 & 1,237 & 13,352 & 0,000 \\
\hline
\end{tabular}

Sumber : Data olahan

Dari Tabel 3 diperoleh variabel yang signifikan adalah variabel harga minyak mentah, variabel harga emas dan variabel moderasi (kurs). Hasil estimasi parameter dapat ditulis sebagai berikut.

$$
Y=-4737,59+8,060 X_{1}+1,938 X_{2}+0,539 Z
$$


Berdasarkan nilai $R^{2}$ Adj yang diperoleh adalah nilai sebesar 0,735 artinya bahwa kemampuan menjelaskan variabel independen terhadap variabel dependen adalah sebesar 73,5\%. Sedangkan sisanya $26,5 \%$ dijelaskan oleh variabel lain diluar variabel independen yang diteliti.

Tabel 4 Hasil Uji F

\begin{tabular}{cccccc}
\hline Model & Sum of Squares & df & Mean Square & F & Sig \\
\hline Regression & $50.583 .281,76$ & 3 & $16.861 .093,92$ & 89,012 & 0,000 \\
Residual & $17.427 .106,34$ & 92 & $189.425,07$ & & \\
Total & $68.010 .388,10$ & 95 & & &
\end{tabular}

Sumber : Data Olahan

Berdasarkan Tabel 4 hasil uji $\mathrm{F}$ diatas dapat dilihat pengaruh simultan variabel independen harga minyak mentah $\left(x_{1}\right)$, harga emas $\left(x_{2}\right)$ dan kurs $(Z)$ terhadap variabel dependen yaitu Indeks Harga Saham Gabungan (Y). Hasil uji simultan diperoleh nilai $F$ hitung sebesar 89,012 dengan nilai signifikansi sebesar 0,000. Berdasarkan nilai signifikansi yang lebih kecil dari 0,05 maka dapat dikatakan bahwa variabel independen dan variabel moderasi $\left(x_{1}, x_{2}\right.$, dan $\left.Z\right)$ secara simultan berpengaruh terhadap Indeks Harga Saham Gabungan (Y) di Bursa Efek Indonesia.

\section{Tabel 5 Hasil Uji T}

\begin{tabular}{cccccc}
\hline \multirow{2}{*}{ Model } & \multicolumn{2}{c}{ Untandardized Coefficients } & Standardized Coefficients & \multirow{2}{*}{ T } & \multirow{2}{*}{ Sig } \\
& B & Std. Error & Beta & & \\
\hline Constant & $-4737,59$ & 831,47 & & $-5,698$ & 0,000 \\
$\log x_{1}$ & 8,060 & 3,134 & 0,222 & 2,572 & 0,012 \\
$\log x_{2}$ & 1,938 & 0,305 & 0,446 & 6,346 & 0,000 \\
$\log Z$ & 0,539 & 0,040 & 1,237 & 13,352 & 0,000 \\
\hline
\end{tabular}

Sumber : Data Olahan

Berdasarkan Tabel 5 hasil uji $\mathrm{T}$ analisis data diatas dapat disimpulkan bahwa :

a. Harga minyak mentah $\left(\log x_{1}\right)$ berpengaruh secara signifikan terhadap Indeks Harga Saham Gabungan (LogY) di Bursa Efek Indonesia. Hal tersebut dapat dilihat dari nilai t hitung $(2,572)>$ $\mathrm{t}$ tabel $(1,986)$ dan nilai signifikannya kurang dari 0,05 yaitu 0,012 maka, secara parsial variabel harga minyak mentah $\left(\log x_{1}\right)$ berpengaruh secara signifikan terhadap Indeks Harga Saham Gabungan (Y) di Bursa Efek Indonesia.

b. Harga emas $\left(\log x_{2}\right)$ berpengaruh secara signifikan terhadap Indeks Harga Saham Gabungan $(\log Y)$ di Bursa Efek Indonesia. Hal tersebut dapat dilihat dari nilai t hitung $(6,346)>t$ tabel $(1,986)$ dan nilai signifikannya kurang dari 0,05 yaitu 0,000 maka, secara parsial variabel harga emas $\left(\log x_{2}\right)$ berpengaruh secara signifikan terhadap Indeks Harga Saham Gabungan (LogY) di Bursa Efek Indonesia.

c. Variabel kurs (Log Z) berpengaruh secara signifikan terhadap Indeks Harga Saham Gabungan (LogY) di Bursa Efek Indonesia. Hal tersebut dapat dilihat dari nilai t hitung $(13,352)>t$ tabel $(1,986)$ dan nilai signifikannya kurang dari 0,05 yaitu 0,000 maka, secara parsial variabel kurs ( $\log Z$ Z) berpengaruh secara signifikan terhadap Indeks Harga Saham Gabungan (Log Y) di Bursa Efek Indonesia.

\section{Uji asumsi Klasik}

a. Uji Normalitas

Pengujian normalitas dilakukan dengan menggunakan uji Kolmogorov-Smirnov. Diperoleh hasil nilai signifikan dari uji Kolmogorov-Smirnov sebesar 0,570 yang lebih dari tingkat signifikan $\alpha=$ 0,05.Sehingga residual dari model regresi berdistribusi normal.

b. Uji Heterokedastisitas

Uji Heterokedastisitas menggunakan uji Glejser. Diperoleh nilai seperti Tabel 6 berikut. 
Tabel 6 Hasil Uji Heterokedastisitas

\begin{tabular}{cccccc}
\hline \multirow{2}{*}{ Model } & \multicolumn{2}{c}{ Untandardized Coefficients } & Standardized Coefficients & \multirow{2}{*}{ T } & \multirow{2}{*}{ Sig } \\
& B & Std. Error & Beta & & \\
\hline Constan & $-45,75$ & 470,19 & & $-0,097$ & 0,923 \\
$x_{1}$ & 1,163 & 1,772 & 0,107 & 0,656 & 0,513 \\
$x_{2}$ & $-0,122$ & 0,173 & $-0,093$ & $-0,704$ & 0,483 \\
Z & 0,041 & 0,023 & 0,317 & 1,816 & 0,073 \\
\hline
\end{tabular}

Sumber : Data Olahan

Berdasarkan Tabel 6 terlihat bahwa semua nilai variabel independen yaitu nilai signifikan $>\alpha$. Karena nilai signifikan $>\alpha=0,05$ artinya asumsi homokedastisitas terpenuhi atau tidak terdapat heterokedastisitas.

c. Uji Multikolinearitas

Metode yang digunakan untuk mendeteksi adanya multikolinearitas dalam penelitian ini dengan Variance Inflation Factor (VIF). Diperoleh nilai seperti Tabel 5 berikut.

Tabel 7 Hasil Uji Multikolinearitas

\begin{tabular}{cccccccc}
\hline & \multicolumn{2}{c}{$\begin{array}{l}\text { Untandardized } \\
\text { Coefficients }\end{array}$} & \multicolumn{2}{c}{$\begin{array}{c}\text { Standardized } \\
\text { Coefficients }\end{array}$} & T & Sig & \multicolumn{2}{c}{ Collinearity Statistics } \\
& B & $\begin{array}{c}\text { Std. } \\
\text { Error }\end{array}$ & Beta & & & Tolerance & VIF \\
\hline Constant & $-4737,59$ & 831,47 & & $-5,698$ & 0,000 & & \\
$x_{1}$ & 8,060 & 3,134 & 0,222 & 2,572 & 0,012 & 0,374 & 2,674 \\
$x_{2}$ & 1,938 & 0,305 & 0,446 & 6,346 & 0,000 & 0,564 & 1,772 \\
Z & 0,539 & 0,040 & 1,237 & 13,352 & 0,000 & 0,324 & 3,084 \\
\hline
\end{tabular}

Sumber : Data Olahan

Berdasarkan hasil pada Tabel 7 hasil uji multikolinearitas diatas menunjukkan bahwa semua variabel independen memiliki nilai VIF tidak lebih dari 10, yang berarti tidak ada gejala multikolinearitas antar variabel independen dalam model regresi.

d. Uji Autokorelasi

Pada uji ini dilakukan dengan menggunakan Uji Durbin Watson. Nilai Durbin Watson yang diperoleh disajikan pada Tabel 8 yaitu sebagai berikut.

Tabel 8 Hasil Uji Autokorelasi

\begin{tabular}{cccccc}
\hline Model & $\mathrm{R}$ & $\mathrm{R}$ Square & Adjusted R Square & Std. Error of the Estimate & Durbin-Watson \\
\hline 1 & 0,862 & 0,744 & 0,735 & 435,23 & 0,328 \\
\hline
\end{tabular}

Sumber : Data Olahan

Pada Tabel 8 terlihat bahwa nilai DW adalah sebesar 0,328 dengan nilai dU sebesar 1,6039. Nilai DW < dU berarti pada data ini terdapat gejala autokorelasi. Maka langkah selanjutnya adalah mentranformasi data dalam bentuk log dan dilakukan pengujian autokorelasi kembali.

Tabel 9 Hasil Tranformasi Log Uji Autokorelasi

\begin{tabular}{cccccc}
\hline Model & $\mathrm{R}$ & R Square & Adjusted R Square & Std. Error of the Estimate & Durbin-Watson \\
\hline 1 & 0,862 & 0,744 & 0,735 & 435,23 & 1,925 \\
\hline
\end{tabular}

Sumber : Data Olahan

Pada Tabel 9 adalah hasil dari transformasi log untuk menghilangkan adanya autokorelasi. Terlihat nilai DW adalah sebesar 1,925. Nilai akan di bandingkan dengan Tabel nilai dL dan dU pada uji DW dengan signifikansi 0,05, jumlah sampel sebanyak 96 sampel dan jumlah variabel independen sebanyak 3 variabel maka diperoleh nilai dU $=1,6039$. Nilai DW 1,925 lebih besar dari batas atas (dU) yakni 1,6039 dan kurang dari $(4-d U)=2,3961$. Karena nilai DW terletak antara dU dan (4-dU) maka dapat disimpulkan bahwa tidak terdapat autokorelasi. 


\section{Uji Regresi Dengan Variabel Moderasi}

Setelah dilakukan uji asumsi klasik, langkah selanjutnya adalah menguji variabel moderasi dengan variabel independen yang signifikan. Hasil estimasi uji regresi ditampilkan pada Tabel 10 yaitu sebagai berikut.

Tabel 10 Estimasi Parameter Uji Regresi dengan Variabel Moderasi

\begin{tabular}{cccccc}
\hline \multirow{2}{*}{ Model } & Untandardized Coefficients & Standardized Coefficients & T & Sig. \\
& B & Std. Error & Beta & 0,862 & 0,391 \\
Constans & 291,864 & 338,609 & & 2,405 & 0,018 \\
$\log X_{1}$ & 42,049 & 17,485 & 1,324 & $-1,511$ & 0,134 \\
$\log X_{2}$ & $-2,309$ & 1,528 & $-0,791$ & 0,677 & 0,500 \\
$\log Z$ & 0,122 & 0,180 & 0,217 & $-2,436$ & 0,017 \\
$\log X_{2} Z$ & $-0,022$ & 0,009 & $-1,194$ & 1,971 & 0,052 \\
$\log X_{2} Z$ & 0,002 & 0,001 & 1,021 & & \\
\hline
\end{tabular}

Sumber : Data Olahan

Berdasarkan Tabel 10 hasil estimasi parameter uji moderasi terlihat bahwa masih ada variabel yang tidak signifikan. Sehingga harus dilakukan pengujian ulang yang pertama dengan mengeluarkan variabel kurs (variabel moderasi). Karena mempunyai nilai signifikan yang besar yaitu 0,500. Kemudian diregresikan kembali pada Tabel 11 hasil estimasi uji regresi dengan variabel moderasi.

Tabel 11 Estimasi Hasil Uji Regresi dengan Variabel Moderasi

\begin{tabular}{cccccc}
\hline \multirow{2}{*}{ Model } & \multicolumn{2}{c}{ Untandardized Coefficients } & Standardized Coefficients & \multirow{2}{*}{ T } & \multirow{2}{*}{ Sig. } \\
& B & Std. Error & Beta & & 6,100 \\
\hline Constants & 513,765 & 84,225 & & 0,000 \\
$\log X_{1}$ & 40,019 & 17,174 & 1,260 & 2,330 & 0,022 \\
$\log X_{2}$ & $-3,098$ & 0,985 & $-1,062$ & $-3,146$ & 0,002 \\
$\log X_{1} Z$ & $-0,021$ & 0,009 & $-1,141$ & $-2,366$ & 0,020 \\
$\log X_{2} Z$ & 0,002 & 0,001 & 1,294 & 4,003 & 0,002 \\
\hline
\end{tabular}

Sumber : Data Diolah SPSS

Berdasarkan hasil estimasi parameter pada Tabel 11 maka persamaan regresi tanpa variabel kurs (variabel moderasi) adalah sebagai berikut :

$$
\log Y=513,765+40,019 \log X_{1}-3,098 \log X_{2^{-}} 0,021 \log X_{1} Z+0,002 \log X_{2} Z
$$

Karena Persamaan 10 masih dalam bentuk Log, maka diubah kedalam bentuk biasa yaitu pada persamaan 10 sebagai berikut.

$$
Y=1,334457 E 223+X_{1}^{40,019}-X_{2}^{3,098}-\left(X_{1} Z\right)^{0,021}+\left(X_{2} Z\right)^{0,002} .
$$

Pada Tabel 11 hasil estimasi parameter sebelum variabel interaksi dimasukkan terlihat bahwa variabel kurs (Z) berpengaruh terhadap Indeks Harga Saham Gabungan (Y), tetapi pada Tabel 7 setelah variabel interaksi dimasukkan terlihat bahwa variabel kurs (Z) menjadi tidak signifikan yang artinya tidak berpengaruh terhadap Indeks Harga Ssaham Gabungan (Y). Sehingga perlu dilakukan regresi ulang tanpa mengikutsertakan variabel kurs (Z). Pada Tabel 11 terlihat bahwa variabel interaksi ( $X_{1} Z$ dan $X_{2} Z$ ) berpengaruh terhadap Indeks Harga Saham Gabungan (Y). Walaupun variabel moderasi tidak berpengaruh terhadap Indeks Harga Saham Gabungan $(Y)$ tetapi variabel moderasi berinteraksi dengan harga minyak mentah $\left(X_{1}\right)$ dan harga emas $\left(X_{2}\right)$. Dengan demikian variabel kurs (Z) merupakan variabel pure moderasi. Pure moderasi merupakan variabel moderasi yang memoderasi hubungan antara variabel independen $(\mathrm{X})$ dan variabel dependen $(\mathrm{Y})$ dimana variabel moderasi murni berinteraksi dengan variabel independen tanpa menjadi variabel independen. 


\section{PENUTUP}

Berdasarkan hasil analysis dan pembahasan pada penelitian ini dapat disimpulkan bahwa :

1. Berdasarkan hasil estimasi model yang diperoleh adalah sebagai berikut $Y=1,334457 E 223+X_{1}^{40,019}-X_{2}^{3,098}-\left(X_{1} Z\right)^{0,021}+\left(X_{2} Z\right)^{0,002}$.

2. Faktor yang mempengaruhi IHSG adalah harga minyak mentah, harga emas, interaksi antara harga minyak mentah dan kurs, dan interaksi antara harga emas dan kurs.

\section{DAFTAR PUSTAKA}

[1]. Ariyanto. Pengembangan Analisis Multivariate dengan SPSS 12. Jakarta: Penerbit Salemba Infotek. 2005.

[2]. Sugiono. Konsep, Identifikasi, Alat Analisis dan Masalah Penggunaan Variabel Moderator. Jurnal Manajemen Strategi. 2004 : 1 (2) : 61-70.

[3]. Suliyanto. Ekonometrika Terapan : Teori dan Aplikasi dengan SPSS. Yogyakarta: Andi. 2011.

[4]. Triyono. Analisis Perubahan Kurs Rupiah Terhadap Dollar Amerika. Jurnal Ekonomi Pembangunan. 2008: 9 (2) : 156-167.

[5]. Rachmawati, I, D. Model regresi variabel dengan Metode Selisih Mutlak. Jurnal Eksponensial. $2015: 6$ (2). 188-192.

[6]. Ghozali, I. Aplikasi Analisis Multivariate Dengan Program IBM SPSS 23. Semarang: Universitas Diponegoro. 2016.

[7]. Muharromah, R. Pemodelan Jumlah Penduduk Miskin Di Kalimantan Dengan Regresi Variable Moderasi. Jurnal Ekponensial. 2014:5 (2) : 118-126.

UMAMAH

: Jurusan Matematika FMIPA Untan, Pontianak, emaalfarizi72@gmail.co 
